\title{
PENGARUH GENDER, DAYA TARIK PROMOSI, KEPEMILIKAN KARTU KREDIT TERHADAP PERILAKU PEMBELIAN IMPULSIF ONLINE PRODUK LIFESTYLE
}

\author{
I Made Santika Putra ${ }^{1}$ \\ I Wayan Santika ${ }^{2}$ \\ ${ }^{1,2}$ Fakultas Ekonomi dan Bisnis Universitas Udayana, Bali, Indonesia \\ e-mail: Udiksantikap21@gmail.com
}

\begin{abstract}
ABSTRAK
Kemajuan teknologi membuat paradigma baru dalam dunia bisnis. Perkembangan penggunaan internet yang sangat cepat akan berdampak positif bagi pelaku bisnis online di Indonesia. Salah satu perilaku konsumen yang sangat diinginkan oleh pemasar yang menggunakan media online adalah perilaku pembelian implusif. Penelitian ini bertujuan untuk mengetahui pengaruh gender, daya tarik promosi dan kepemilikan kartu kredit terhadap perilaku pembelian impulsif secara online. Penelitian ini dilakukan di Kota Denpasar dengan melibatkan 60 orang responden melalui metode purposive sampling Metode ini dipilih karena tidak diketahui secara pasti jumlah populasinya. Data dikumpulkan melalui penyebaran kuesioner. Teknik analisis data yang digunakan adalah teknik analisis regresi linear berganda. Hasil penelitian ini menemukan bahwa gender berpengaruh positif dan signifikan terhadap perilaku pembelian impulsif online, daya tarik promosi secara positif dan signifikan memengaruhi perilaku pembelian impulsif online dan kepemilikan kartu kredit berpengaruh positif dan signifikan terhadap perilaku pembelian impulsif online. Pihak pemasar diharapkan mampu lebih teliti dalam menentukan segmentasi pasar, lebih kreatif dalam melakukan promosi serta mampu memberikan kemudahan dan kenyamanan dalam proses pembayaran saat berbelanja online.
\end{abstract}

Kata kunci: gender, daya tarik promosi, kepemilikan kartu kredit, perilaku pembelian impulsif.

\footnotetext{
ABSTRACT

Technological advances create a new paradigm in the business world. The rapid development of internet usage will have a positive impact for online business in Indonesia. One of the most desirable consumer behavior by marketers who use online media is the implusive purchase behavior. This study aims to determine the effect of gender, attractiveness of promotion and ownership of credit cards against impulsive buying behavior online. This research was conducted in Denpasar City involving 60 respondents through purposive sampling method. This method was chosen because it is not known exactly the number of population. Data were collected through questionnaires. Data analysis technique used is multiple linear regression analysis technique.The results of this study found that gender positively and positively affects online impulsive buying behavior, promotional appeal positively and significantly affects online impulsive buying behavior and credit card ownership positively and significantly affects online impulsive buying behavior. Marketers are expected to be more accurate in determining market segmentation, more creative in promoting and able to provide convenience and convenience in the payment process when shopping online.

Keywords: gender, attraction of promotion, credit card ownership, impulsive buying behavior.
} 


\section{PENDAHULUAN}

Perkembangan globalisasi menuntut segala sesuatu menjadi lebih cepat dan efisien. Kemajuan teknologi membuat paradigma baru dalam dunia bisnis. Pemikiran manusia moderen menginginkan proses transaksi yang lebih cepat dan praktis. Internet merupakan salah satu kemajuan teknologi yang mampu membantu manusia untuk melakukan kegiatan dengan cepat dan efisien. Internet juga merupakan sebuah media penting dalam pengambilan keputusan karena memuat informasi yang dapat diakses secara bebas.

Lembaga riset pasar $e$-marketer menyatakan, populasi pengguna internet di Indonesia mencapai 83,7 juta orang pada Tahun 2014. Pada Tahun 2017, emarketer memperkirakan pengguna internet di Indonesia mencapai 112 juta orang, (tempo.com, 2016). Nielsen Indonesia dalam Goh et al. (2012) menyatakan bahwa sebanyak $68 \%$ pengguna internet di Indonesia melakukan transaksi online paling sedikit satu kali. Adanya internet dalam dunia bisnis mempermudah jarak antara konsumen terhadap produsen dikarenakan internet akan menghubungkan konsumen akhir (end-users) dengan produsen secara langsung. Adanya perkembangan internet akan menciptakan interaksi yang potensial dengan pelanggan pada skala global (Arnott dan Bridgewater, 2002:87).

Akses internet yang semakin cepat akan memengaruhi perilaku konsumen. Perilaku belanja yang dilakukan oleh konsumen menggunakan media online merupakan cerminan gaya hidup masyarakat di zaman moderen. Belanja merupakan salah satu gaya hidup tersendiri yang menjadi suatu kegemaran bagi 
I Made Santika Putra, Pengaruh Gender, Daya Tarik...

sejumlah orang, selain itu belanja juga merupakan alat pemuas serta kebutuhan oleh beberapa orang. Kebutuhan konsumen saat ini mengarah pada konsep lifestyle yang sesuai dengan kebutuhannya (Sari, 2013). Terdapat tiga produk lifestyle yang sering dibeli secara online oleh orang Indonesia yaitu kebutuhan rumah tangga, fashion, dan gadget (Liputan6.com, 2017).

Perilaku impulsif merupakan salah satu dari perilaku konsumen saat sedang berbelanja. Fenomena impulse buying terjadi di seluruh negara tidak terkecuali di Indonesia. Rook dan Fisher (1995) menyatakan bahwa sangat potensial bagi konsumen untuk melakukan pembelian impulsif secara online. Impulse buying merupakan bagian dari kondisi yang dinamakan Uplanned Purchase yang kurang lebih adalah pembelanjaan yang terjadi ternyata berbeda dengan perencanaan pembelanjaan seorang konsumen (Fitriani, 2010).

Berbelanja online dapat dilakukan dimana saja selama terdapat jaringan koneksi dengan internet dan praktis dalam menggunakannya (Saragih dan Rizky, 2012). Kemudahan menjadi keunggulan bagi konsumen dalam melakukan perbelanjaan online. Salah satu perilaku konsumen yang sangat diinginkan oleh pemasar yang menggunakan media online adalah perilaku pembelian implusif. Impulse buying adalah fenomena umum di pasar moderen dan telah menjadi titik fokus bagi kegiatan pemasaran secara moderen (Graa et al., 2014).

Konsumen yang melakukan perilaku impulse buying tidak berpikir untuk membeli produk atau merek tertentu, konsumen langsung melakukan pembelian karena ketertarikan pada merek atau produk saat itu juga. Berdasarkan pengertian 
di atas Impulse buying adalah perilaku konsumen yang tidak merencanakan atau mempersiapkan sesuatu dalam berbelanja. Perilaku pembelian tidak terencana terjadi karena perasaan nyaman dalam berbelanja dan karena adanya karakteristik demografis seperti gender atau pun usia (Mudzalifa, 2015).

Penelitian yang dilakukan oleh Tifferet dan Ram (2012) menyatakan perempuan memiliki dorongan yang lebih tinggi dalam pembelian dibandingkan dengan laki-laki, berbeda dengan penelitian oleh Ali dan Hasnu (2013) yang menyatakan pria menunjukkan pembelian impulsif lebih tinggi dari pada perempuan karena perempuan berhati-hati dalam rencana pembelian mereka. Secara tidak langsung gender merupakan salah satu penyebab dalam perilaku pembelian impulsif, online. Menurut park dan Keller (2009:237) kebutuhan dan keinginan konsumen berkaitan erat dengan gender (jenis kelamin). Gender merupakan suatu status yang membedakan manusia. Berdasarkan pemaparan tersebut gender dapat dikatakan sebagai perbedaan peran, fungsi dan tanggung jawab laki-laki dan perempuan yang menghasilkan konstruksi sosial yang dapat berubah sesuai perkembangan zaman.

Salah satu cara yang dapat dilakukan secara positif untuk mampu mempengaruhi seseorang melakukan pembelian impulsif adalah promosi (Park dan Lenon, 2009). Daya tarik promosi merupakan bagian dari promosi yang sangat penting dilakukan oleh pemasar untuk meningkatkan penjualan serta memikat minat beli konsumen. Pemasaran dengan sistem yang lebih moderen dapat menjangkau konsumen lebih luas. Cummins dan Mullin (2004: 41) mengungkapkan bahwa salah satu tujuan dari promosi penjualan adalah 
menciptakan ketertarikan dan mengalihkan ketertarikan pada harga. Daya tarik promosi dapat diketahui dengan beberapa hal antara lain, produk gratis, harga diskon dan voucher yang mampu menjadi alasan untuk melakukan pembelian tak berencana (Karbasivar dan Yarahmadi, 2011).

Keterbatasan bukan merupakan suatu masalah bagi konsumen dalam berbelanja di zaman moderen. Keterbatasan tersebut dapat ditutupi dengan adanya kemajuan teknologi. Pamor kartu kredit di Indonesia adalah sebagai alat transaksi non tunai selain kartu debet dan kartu ATM, perlahan-lahan semakin meroket. Sampai akhir Maret 2017 lalu, jumlah kartu kredit yang beredar di Indonesia mencapai 17,59 juta unit kartu, berdasarkan data Bank Indonesia (halamoney.co.id).

Menurut Safakli (2007) menyatakan bahwa motivasi kepemilikan dan penggunaan kartu kredit dipengaruhi oleh faktor kenyamanan, kemudahan dan keamanan saat menggunakannya. Park dan Burns (2005), menyatakan bahwa semakin besar limit dari kartu kredit, maka semakin besar kemungkinan orang untuk melakukan pembelian impulsive online. Adanya kartu kredit sebagai salah satu penunjang konsumen dalam melakukan pembelian membuat konsumen bebas melakukan pembelian.

Pemilik kartu kredit mengharapkan proses transaksi yang lebih modern. Dalam usaha untuk memenuhi kebutuhan, konsumen cenderung secara rasional menggunakan sumber daya terbatas untuk mencapai tingkat kepuasan maksimal (Saleh, 2012). Penggunaan kartu kredit berkaitan dengan kelas sosial, tingkat 
penghasilan serta gaya hidup penggunanya. Peraturan Bank Indonesia (PBI No.7/52/PBI/2005) dalam Sayono dkk. (2009: 62) mendefinisikan kartu kredit merupakan alat pembayaran dengan menggunakan kartu yang digunakan untuk melakukan pembayaran atas kewajiban dari suatu kegiatan ekonomi dan pemegang kartu berkewajiban melakukan pelunasan dan kewajiban pada waktu yang ditentukan, baik secara langsung ataupun angsuran.

Berdasarkan fenomena yang sudah dipaparkan sebelumnya menunjukan bahwa perilaku pembelian impulsif tidak hanya terjadi pada gerai-gerai toko tetapi terjadi juga secara online yang merupakan dampak dari kemajuan teknologi di zaman globalisasi ini. Perbedaan pendapat pada variabel gender memberi pembeda pada penelitian sebelumnya sehingga kebaruan dalam penelitian ini dapat menjawab gap yang terjadi terkait perilaku pembelian impulsif online. Pembelian impulsif online ini merupakan hal penting yang harus diketahui oleh pemasar, maka perlu dilakukan penelitian untuk membuktikan bagaimana gender, daya tarik promosi, dan kepemilikan kartu kredit mempengaruhi konsumen Indonesia dalam melakukan pembelian impulsif secara online.

Melihat latar belakang yang telah dijabarkan, adapun pokok permasalahan pada penelitian ini yaitu: 1) Bagaimanakah pengaruh gender terhadap perilaku pembelian impulsif online?; 2) Bagaimanakah pengaruh daya tarik promosi terhadap perilaku pembelian impulsif online?; 3) Bagaimanakah pengaruh kepemilikan kartu kredit terhadap perilaku pembelian impulsif online?. 
Berdasarkan pokok permasalahan yang telah diuraikan, adapaun tujuan dari penelitian ini yaitu: 1) Untuk menjelaskan pengaruh gender terhadap perilaku pembelian impulsif online; 2) Menjelaskan pengaruh daya tarik promosi terhadap perilaku pembelian impulsif online; 3) Menjelaskan pengaruh kepemilikan kartu kredit terhadap perilaku pembelian impulsif online.

Secara Teoritis, penelitian ini diharapkan dapat dijadikan bukti empiris untuk menambah pengetahuan khususnya dalam bidang ilmu manajemen pemasaran yang perilaku pembelian impulsif online dan kaitannya dengan gender, daya tarik promosi dan kepemilikan kartu kredit. Secara praktis diharapkan hasil dalam penelitian ini dapat dijadikan acuan maupun pertimbangan bagi seluruh pihak yang ingin memasarkan produknya secara online, sehingga mampu menciptakan pembelian impulsif online.

Ali and Hasnu (2013) menyatakan jenis kelamin merupakan penyebab penting untuk perilaku impulse buying baik online maupun offline. Jenis kelamin menjadi karakteristik demografis yang sangat perlu untuk dibicarakan karena terbukti bahwa laki-laki dan perempuan memproses informasi secara berbeda (Peter \& Olson, 1999). Penelitian yang dilakukan oleh Widawati (2011) memperoleh hasil bahwa jenis kelamin memiliki pengaruh yang signifikan terhadap keputusan pembelian tidak terencana yang menyatakan. Berdasarkan pernyataan oleh studi empiris terdahulu, dapat disimpulkan hipotesis pertama yakni: $\mathrm{H}_{1}$ : Gender berpengaruh positif dan signifikan terhadap perilaku pembelian impulsif online. 
Menurut Tjiptono (2008) menyatakan bahwa melalui promosi penjualan, perusahaan dapat menarik konsumen baru. Menurut David S Simatupang (Marketing, 2007) dalam penelitian Arifianti (2011) menyatakan bahwa tujuan dari promosi penjualan adalah meningkatkan volume penjualan dengan menciptakan tampilan dan aktivitas yang menarik untuk mendorong perilaku impulse buying. Kurniawan et al., (2013) menyatakan bahwa daya tarik promosi berpengaruh positif dan signifikan terhadap pembelian impulsif online karena saat promosi gecar dilakukan, maka konsumen lebih tertarik untuk melakukan impulsif online. Berdasarkan pernyataan oleh studi empiris terdahulu, dapat disimpulkan hipotesis kedua yakni: $\mathrm{H}_{2}$ : Daya tarik promosi berpengaruh positif dan signifikan terhadap perilaku pembelian impulsif online.

Penelitian yang dilakukan oleh Mahaputra (2014), menyatakan bahwa kepemilikan kartu kredit secara signifikan berpengaruh positif terhadap perilaku pembelian impulsif online di Indonesia, dikarenakan konsumen cenderung menggunakan hingga batas maksimum, yang berarti kepemilikan kartu kredit mempengaruhi pembelian impulsif secara online. Saleh (2012) menyatakan bahwa kartu kredit berpengaruh positif terhadap perilaku pembelian impulsif karena semakin besar limit kartu kredit konsumen, maka konsumen lebih cenderung melakukan pembelian impulsif. Berdasarkan pernyataan oleh studi empiris terdahulu, dapat disimpulkan hipotesis ketiga yakni: $\mathrm{H}_{3}$ : Kepemilikan kartu kredit berpengaruh positif dan signifikan terhadap perilaku pembelian impulsif online.

Kerangka konseptual dalam penelitian ini mengacu pada penelitian empiris terdahulu yang dilakukan oleh Mahaputra (2014) sebagai berikut: 


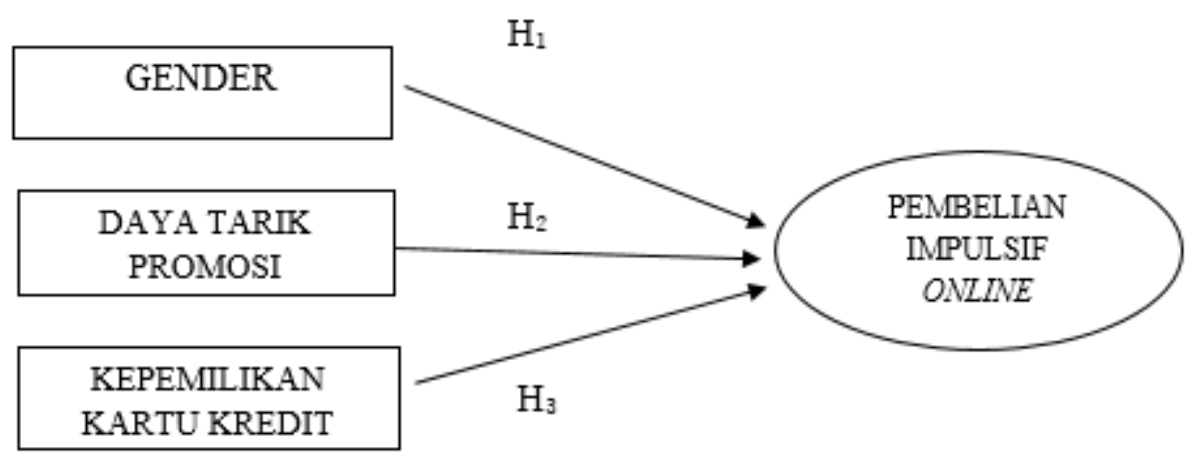

Gambar 1. Kerangka Konseptual Penelitian

Sumber: Mahaputra, 2014

\section{METODE PENELITIAN}

Penelitian ini dilakukan di Kota Denpasar khususnya bagi konsumen yang menggunakan internet untuk melakukan pembelian secara online. Jenis data dalam penelitian ini yaitu data kualitatif dan kuantitatif. Data kualitatif yaitu tanggapan partisipan atas butir-butir pernyataan yang telah diberikan pada kuesioner yang telah diberi skali likert. Data kuantitatif yang digunakan yaitu data pengguna internet Indonesia, data pengguna kartu kredit Indonesia. Sumber primer dalam penelitian ini adalah responden masyarakat Kota Denpasar yang terpilih sebagai sampel responden sesuai dengan kriteria yang ditentukan. Sumber sekunder dalam penelitian ini adalah studi empiris pada penelitian sebelumnya, serta berita dan data yang dikutip dari media online terkait dengan variabel yang diteliti. Variabel dalam penelitian ini dibagi menjadi dua jenis yaitu variabel terikat yaitu perilaku pembelian impulsif online dan variabel bebas yaitu gender, daya tarik promosi dan kepemilikan kartu kredit.

Pada penelitian ini yang termasuk dalam populasi adalah semua konsumen di Kota Denpasar yang pernah berbelanja online. Teknik pengambilan sampel 
yang digunakan yaitu teknik non probability sampling yang berbentuk purposive sampling dan teknik sloveign yang sesuai dengan kriteria tertentu. Dalam penelitian ini, sampel diambil sejumlah 60 responden yaitu konsumen yang pernah berbelanja secara online di Kota Denpasar berdasarkan kriteria tertentu, didukung oleh pernyataan Ferdinand (2002:47) yang menyatakan jumlah sampel yang ideal adalah 5-10 kali jumlah indikator.

\section{Tabel 1.}

\section{Indikator Variabel}

\begin{tabular}{lll}
\hline \multicolumn{1}{c}{ Variabel } & \multicolumn{1}{c}{ Indikator Variabel } & \multicolumn{1}{c}{ Sumber } \\
\hline Gender & \multicolumn{1}{c}{ Ali dan Hasnu (2013) } \\
\hline Promosi & $\begin{array}{l}\text { 1. Diskon (X2.1) } \\
\text { 2. Sampel Gratis (X2.2) } \\
\text { 3.Voucher (X2.3) }\end{array}$ & $\begin{array}{l}\text { Karbasivar dan } \\
\text { Yarahmadi (2011) }\end{array}$ \\
\hline $\begin{array}{l}\text { Kepemilikan Kartu } \\
\text { Kredit }\end{array}$ & - & Park dan Burns (2005) \\
\hline $\begin{array}{l}\text { Pembelian Impulsif } \\
\text { Buying Online }\end{array}$ & $\begin{array}{l}\text { 1. Pembelian tanpa berpikir akibat } \\
\text { (Y1.1) }\end{array}$ & \\
& $\begin{array}{l}\text { 2. Pembelian spontan (Y1.2) } \\
\text { 3. Pembelian terburu-buru (Y1.3) } \\
\text { 4. Pembelian dipengaruhi keadaan } \\
\text { emosional (Y1.4) }\end{array}$ & \\
&
\end{tabular}

Data dalam penelitian ini dilakukan melalui survei dengan instrumen penelitian menggunakan kuesioner sebagai salah satu sumber data sehingga perlu dilakukannya pengujian validitas, reliabilitas agar kuesioner layak dan akurat untuk digunakan sebagai sumber data penelitian. Indikator variabel penelitian diukur dengan menggunakan 1 sampai 5 skala likert (Sugiono, 2010: 133).

\section{HASIL DAN PEMBAHASAN}


Karakteristik responden dapat dilihat pada Tabel 2 Berdasarkan variabel usia pada penelitian ini didominasi oleh usia 17-23 tahun sebanyak 46 orang atau 75,4 persen, hal tersebut menunjukan bahwa pada penelitian ini, konsumen yang bertransaksi secara online didominasi oleh rentang usia 17-23 tahun sesuai pernyataan Mahaputra (2014) bahwa konsumen online di Indonesia masih didominasi kaum muda.

Tabel 2.

Karakteristik Demografi Responden

\begin{tabular}{ccccc}
\hline No & Variabel & Klasifikasi & $\begin{array}{c}\text { Jumlah } \\
\text { (orang) }\end{array}$ & Persentase (\%) \\
\hline 1 & Jenis Kelamin & Perempuan & 30 & 50 \\
& & Laki-laki & 30 & 50 \\
& & Total & 60 & 100 \\
\hline \multirow{2}{*}{2} & Usia & 17th - 23th & 45 & 75,4 \\
& & 24 th - 30th & 10 & 16,4 \\
& & 31 th - 40th & 3 & 4,9 \\
& & 241 th & 2 & 3,3 \\
& & Total & 60 & 100 \\
\hline \multirow{2}{*}{3} & Pendidikan Terakhir & SLTA & 28 & 46 \\
& & S1 & 30 & 50 \\
& & S2 & 2 & 4 \\
& & Jumlah & 60 & 100 \\
\hline
\end{tabular}

Sumber: Data Primer Diolah, 2018

Berdasarkan pendidikan terakhir didominasi oleh S1 sebesar 50 persen, data tersebut menunjukan bahwa pada penelitian ini, berdasarkan tingkat pendidikan terakhir konsumen online telah mengecap pendidikan yang berkaitan dengan pemahaman terhadap sebuah proses pemasaran, sehingga dapat direspon dan dipahami oleh konsumen.

Tabel 3 menunjukan alat yang digunakan konsumen untuk online. Smartphone menjadi alat yang paling banyak digunakan oleh konsumen untuk melakukan pembelanjaan secara online sebesar 91.7 persen, yang menunjukan 
alat-alat tersebut berkaitan dengan tampilan dan format pemesan dari situs perbelanjaan yang diakses oleh konsumen saat sedang online.

Tabel 3.

Alat yang digunakan Responden Untuk Online

\begin{tabular}{cccc}
\hline No & Alat & Jumlah (orang) & Persentase (\%) \\
\hline 1 & Smartphone & 55 & 91,7 \\
2 & PC/Laptop & 4 & 6,6 \\
3 & Tablet & 1 & 1,7 \\
\hline \multicolumn{2}{l}{ Sumber: Data Primer Diolah, 2018 }
\end{tabular}

Pada Tabel 4 menunjukan total pembelanjaan responden dalam kurun tiga bulan terakhir. Konsumen wanita yang memiliki kartu kredit menunjukan total transaksi pembelanjaan online yang paling tinggi sebesar 36 kali.

Tabel 4.

Jumlah Transaksi Pembelian Impulsif Online Dalam Kurun Tiga Bulan Terakhir

\begin{tabular}{ccc}
\hline No & Konsumen & Total Transaksi perbelanjaan Online \\
\hline 1 & Wanita Yang Memiliki Kartu Kredit & 36 \\
2 & Pria Yang Memiliki Kartu Kredit & 31 \\
3 & Wanita Yang Tidak Memiliki Kartu Kredit & 25 \\
4 & Pria Yang Tidak Memiliki Kartu Kredit & 17 \\
\hline
\end{tabular}

Sumber: Data Primer Diolah, 2018

Berdasarkan Tabel 5 memaparkan bahwa 53,3 persen responden menggunakan ATM sebagai alat pembayaran dalam bertransaksi online. Data ini menunjukan bahwa konsumen lebih menggunakan ATM dalam bertransaksi dari pada jenis alat pembayaran berupa Mbanking, Ibanking dan gerai toko.

Tabel 5.

Alat yang Digunakan Responden yang Tidak Memiliki Kartu Kredit

\begin{tabular}{llll}
\hline No & Alat & Jumlah (Orang) & Presentase $(\%)$ \\
\hline
\end{tabular}




\begin{tabular}{cccc}
1 & ATM & 16 & 53,3 \\
2 & Ibanking & 2 & 6,6 \\
3 & Mbanking & 11 & 36,7 \\
4 & Gerai Toko & 1 & 3,3 \\
\hline
\end{tabular}

Pengujian instrumen pada penelitian ini menggunakan dua pengujian yaitu uji validitas dan uji reliabilitas. Tabel 6 merupakan hasil dari uji validitas yang menunjukan bahwa seluruh koefisien korelasi dari indikator variabel yang diuji menunjukan nilai $r>0,3$ yang berarti bahwa seluruh indikator pada penelitian ini terbukti valid (Sugiyono, 2010: 172).

Tabel 6.

Hasil Uji Validitas

\begin{tabular}{cccc}
\hline Variabel & Indikator & Koefisien Korelasi & Keterangan \\
\hline Daya Tarik Promosi & X2.1 & 0,84 & Valid \\
& X2.2 & 0,77 & Valid \\
& X2.3 & 0,85 & Valid \\
Perilaku Pembelian Impulsif Online & $\mathrm{Y} 1$ & 0,83 & Valid \\
& $\mathrm{Y} 2$ & 0,86 & Valid \\
& $\mathrm{Y} 3$ & 0,4 & Valid \\
& $\mathrm{Y} 4$ & 0,74 & Valid \\
\hline
\end{tabular}

Sumber: Data Primer Diolah, 2018

Pada Tabel 7 menunjukan hasil dari pengujian reliabilitas variabel instrumen penelitian ini terbukti reliabel yang berarti seluruh variabel telah memenuhi syarat untuk digunakan sebagai instrumen penelitian. Hal ini dapat dilihat dari koefisien Cronbach's Alpha variabel lebih besar dari 0,60 ( Sugiyono,2009:189)

Tabel 7. Hasil Uji Reliabilitas 


\begin{tabular}{|c|c|c|c|}
\hline No & Variabel & $\begin{array}{c}\text { Koefisien } \\
\text { Cronbach's Alpha } \\
\end{array}$ & Keterangan \\
\hline 1 & Daya Tarik Promosi & 0,764 & Reliabel \\
\hline 2 & $\begin{array}{l}\text { Perilaku Pembelian Impulsif } \\
\text { Online }\end{array}$ & 0,805 & Reliabel \\
\hline
\end{tabular}

Sumber: Data Primer Diolah, 2018

Gender merupakan variable dummy, sehinga perempuan dikategorikan dengan angka 1 dan Laki-laki dengan angka 0. Paparan dari jumlah responden perempuan dan laki-laki dapat dilihat pada Tabel 8 yang menunjukan keseimbangan antara responden perempuan dan laki-laki.

Tabel 8.

Deskripsi pendistribusian Responden Berdasarkan Gender

\begin{tabular}{ccc}
\hline Gender & frekuensi & persentase $(\%)$ \\
\hline 0 & 30 & 50 \\
1 & 30 & 50 \\
Jumlah & 60 & 100 \\
\hline
\end{tabular}

Sumber: Data Primer Diolah, 2018

Variabel daya tarik promosi ini diukur dengan tiga indikator dan ditanggapi dengan menggunakan lima poin skala Likert. Tanggapan dari responden secara rinci dapat dilihat pada Tabel 9.

Pada Tabel 9 menunjukan rata-rata tanggapan responden terhadap daya tarik promosi sebesar 3,82 yang berarti bahwa angka tersebut termasuk dalam kategori setuju yang menunjukan daya tarik promosi terhadap perilaku konsumen dalam berbelanja onlne di kota Denpasar berpengaruh dalam melakukan pembelian impulsif secara online. "Ketika saya melihat diskon yang mengejutkan, membuat saya tertarik untuk membeli lebih banyak produk", merupakan tanggapan responden dengan skor tertinggi yaitu 3,92, hal ini meunjukan pada penelitian ini 
konsumen online di Kota Denpasar yang menyadari adanya diskon cenderung untuk melakukan pembelian secara impulsif.

Tabel 9.

Deskripsi Tanggapan Responden Terhadap Daya Tarik Promosi

\begin{tabular}{|c|c|c|c|c|c|c|c|c|}
\hline \multirow{2}{*}{ No } & \multirow{2}{*}{ Indikator } & \multicolumn{5}{|c|}{ Skala } & \multirow{2}{*}{$\begin{array}{l}\text { Rata- } \\
\text { Rata }\end{array}$} & \multirow{2}{*}{ Kriteria } \\
\hline & & 1 & 2 & 3 & 4 & 5 & & \\
\hline 1 & $\begin{array}{l}\text { Ketika saya melihat diskon yang } \\
\text { mengejutkan, membuat saya tertarik untuk } \\
\text { membeli lebih banyak produk. }\end{array}$ & 1 & 3 & 13 & 26 & 17 & 3,92 & Setuju \\
\hline 2 & $\begin{array}{l}\text { Sampel gratis yang disertakan pada produk } \\
\text { yang dipasarkan membuat saya tertarik untuk } \\
\text { membeli produk tersebut }\end{array}$ & 1 & 2 & 19 & 31 & 7 & 3,68 & Setuju \\
\hline 3 & $\begin{array}{l}\text { Voucher yang diberikan meningkatkan niat } \\
\text { saya untuk membeli produk yang ditawarkan. }\end{array}$ & 1 & 0 & 16 & 31 & 12 & 3,88 & Setuju \\
\hline & Jumlah & & & & & & 3,82 & Setuju \\
\hline
\end{tabular}

Variabel Kepemilikan kartu kredit dalam penelitian ini merupakan variabel dummy yang mengkategorikan konsumen yang memiliki kartu kredit dengan angka 1 dan konsumen yang tidak memiliki kartu kredit diberi angka 0. Paparan dari jumlah responden terkait kepemilikan kartu kredit dapat dilihat pada Tabel 10.

Tabel 10.

Deskripsi pendistribusian Responden Berdasarkan Kartu Kredit

\begin{tabular}{ccc}
\hline $\begin{array}{c}\text { kepemilikan kartu } \\
\text { kredit }\end{array}$ & frekuensi & persentase $(\%)$ \\
\hline 0 & 30 & 50 \\
1 & 30 & 50 \\
Jumlah & 60 & 100 \\
\hline
\end{tabular}

Sumber: Data Primer Diolah, 2018

Variabel pembelian impulsif online berfungsi sebagai variabel terikat. Tanggapan responden terkait dengan pembelian impulsif online dapat dilihat pada

Tabel 11 Peluang adanya perilaku dalam perilaku pembelian impulsif secara 
online dapat diketahui dari adanya tanggapan terhadap empat pernyataan yang memperoleh rata-rata skor tertinggi.

Tabel 11.

Deskripsi Tanggapan Responden Terhadap Perilaku Pembelian Impulsif Online

\begin{tabular}{|c|c|c|c|c|c|c|c|c|}
\hline \multirow{2}{*}{ No } & \multirow{2}{*}{ Pernyataan } & \multicolumn{5}{|c|}{ Skala } & \multirow{2}{*}{$\begin{array}{l}\text { Rata- } \\
\text { Rata }\end{array}$} & \multirow{2}{*}{ Kriteria } \\
\hline & & 1 & 2 & 3 & 4 & 5 & & \\
\hline 1 & $\begin{array}{l}\text { Saya sering membeli barang secara online } \\
\text { tanpa berpikir panjang }\end{array}$ & 4 & 19 & 16 & 15 & 6 & 3 & $\begin{array}{l}\text { Cukup } \\
\text { Setuju }\end{array}$ \\
\hline 2 & $\begin{array}{l}\text { "Beli sekarang berpikir belakangan" } \\
\text { menjelaskan ketika saya berbelanja online }\end{array}$ & 7 & 21 & 9 & 19 & 4 & 2,87 & $\begin{array}{l}\text { Cukup } \\
\text { Setuju }\end{array}$ \\
\hline 3 & $\begin{array}{l}\text { Terkadang saya merasa terpacu untuk membeli } \\
\text { barang saat sedang online }\end{array}$ & 2 & 17 & 13 & 26 & 10 & 3,62 & Setuju \\
\hline 4 & $\begin{array}{l}\text { Saya Sering tidak sadar akan apa yang sudah } \\
\text { saya beli secara online }\end{array}$ & 5 & 22 & 13 & 16 & 4 & 2,87 & $\begin{array}{l}\text { Cukup } \\
\text { Setuju }\end{array}$ \\
\hline & Jumlah & & & & & & 4,12 & Setuju \\
\hline
\end{tabular}

Sumber: Data Primer Diolah, 2018

Tingginya skor pada pernyataan "Terkadang saya merasa terpacu untuk membeli barang saat sedang online" merupakan sebuah peluang atau kesempatan bagi pemasar dalam memasarkan barang/jasa menggunakan media online. Perilaku impulsif juga dapat didukung dengan penampilan produk yang mampu membuat konsumen merasa senang, serta keamanan transaksi yang memberikan perasaan aman ketika konsumen melakukan pembelanjaan secara online.

Hasil regresi linear berganda menunjukan bahwa semua variabel bebas secara parsial berpengaruh secara signifikan. Hal ini dibuktikan dengan melihat hasil signifikansi setiap variabel bebas kurang dari 0,05 atau $\alpha<5 \%$. Hasil uji regresi linear berganda disajikan pada Tabel 12 di bawah ini. 
Tabel 12. Hasil Uji Regresi Linear Berganda

\begin{tabular}{rlrrrrr}
\hline Model & & Unstandardized Coefficients & $\begin{array}{l}\text { Standardized } \\
\text { Coefficients } \\
\end{array}$ & \multicolumn{1}{c}{ Beta } & Sig. \\
\hline & (Constant) & .729 & 2.820 & & .258 & .797 \\
1 & X1 & .311 & .044 & .320 & 2.282 & .025 \\
& X2 & .583 & .079 & .479 & 4.299 & .004 \\
& X3 & .273 & .120 & .272 & 2.266 & .036 \\
\hline
\end{tabular}

Sumber: Data Primer Diolah, 2018

Dari hasil analisis regresi tidak ditemukannya pengaruh negatif variabel bebas terhadap variabel terikat. Dari ketiga variabel tersebut, variabel jenis kelamin menunjukan bahwa jenis kelamin/gender yang lebih impulsif secara online adalah jenis kelamin perempuan, sedangkan dalam kepemilikan kartu kredit responden yang lebih impulsif yaitu responden yang memiliki kartu kredit ini berarti bahwa konsumen online di Kota Denpasar yang memiliki kartu kredit lebih tertarik untuk melakukan pembelanjaan online yang tidak terencana karena didukung oleh kenyamanan dalam menggunakan kartu kredit. Variabel daya tarik promosi merupakan variabel yang memiliki pengaruh paling besar dalam perilaku impulsif online yang diurutkan berdasarkan Standardized Coefficients Beta.

Uji asumsi klasik bertujuan untuk lebih meyakinkan atas kelayakan model yang dibuat, terutama untuk memprediksi (Utama, 2012: 99). Suatu model regresi dikatakan baik apabila model tersebut terbebas dari asumsi klasik statistik. Uji asumsi klasik meliputi uji normalitas, multikolinearitas dan uji heteroskedastisitas.

Dalam uji normalitas banyak metode yang dapat digunakan salah satu nya dengan uji Komogrov-Smirnov. Paparan uji Komogrov-Smirnov dapat dilihat pada Tabel 13. 
Tabel 13.

Hasil Uji Normalitas

One-Sample Kolmogorov-Smirnov Test

Unstandardized Residual

\begin{tabular}{lr}
\hline $\mathrm{N}$ & 60 \\
Kolmogorov-Smirnov Z & 1.039 \\
Asymp. Sig. (2-tailed) & .231 \\
\hline
\end{tabular}

Sumber: Data Primer Diolah, 2018

Pada kolom standardized residual menunjukan nilai Komogrov-Smirnov sebesar 1,03 dan nilai Asymp. Sig. (2-tailed) sebesar 0,231 yang menunjukan bahwa model regresi pada penelitian ini berdistribusi normal, dibuktikan dengan nilai signifikansi yang lebih besar dari yang diharapkan (Asymp. Sig. (2-tailed $\geq$ $0,05)$.

Model regresi yang baik seharusnya tidak terjadi korelasi antara variabel atau terhindar dari multikolinear. Tabel 14 memaparkan hasil uji multiokolinearitas pada penelitian ini.

Tabel 14.

Hasil Uji Multikolinearitas

\begin{tabular}{|c|c|c|c|c|c|c|}
\hline \multirow{2}{*}{\multicolumn{2}{|c|}{ Model }} & \multicolumn{2}{|c|}{ Unstandardized Coefficients } & \multirow{2}{*}{$\begin{array}{c}\text { Standardized } \\
\text { Coefficients } \\
\text { Beta } \\
\end{array}$} & \multicolumn{2}{|c|}{ Collinearity Statistics } \\
\hline & & $B$ & Std. Error & & Tolerance & VIF \\
\hline \multirow{4}{*}{1} & (Constant) & .729 & 2.820 & & & \\
\hline & $\mathrm{X} 1$ & .311 & .044 & .320 & 1.000 & 1.000 \\
\hline & $\mathrm{X} 2$ & .583 & .079 & .479 & .936 & 1.069 \\
\hline & $\mathrm{X} 3$ & .273 & .120 & .272 & .936 & 1.069 \\
\hline
\end{tabular}

Sumber: Data Primer Diolah, 2018

Berdasarkan pemaparan Tabel 14 dapat disimpulkan bahwa tidak terjadi gejala multikolinearitas antara variabel dalam model regresi. Kesimpulan tersebut dapat dilihat dari nilai tolarance pada setiap variabel lebih besar dari nilai yang 
I Made Santika Putra, Pengaruh Gender, Daya Tarik...

diharapkan $(0,10)$. Perhitungan VIF juga menunjukan semua variabel bebas memiliki nilai kurang dari 10 (tolarance dari $10 \%$ atau VIF <10).

Dalam uji heteroskedastisitas, suatu persamaan regresi dikatakan tidak terjadinya gejala heteroskedastisitas apabila nilai signifikansi seluruh variabel berada di atas 0,05. Tabel 15 menunjukan nilai signifikansi seluruh variabel di atas nilai yang ditentukan $(0,05)$ yang menunjukan tidak adanya pengaruh variabel bebas terhadap absolut residual.

Tabel 15.

Hasil Uji Heteroskedastisitas

\begin{tabular}{|c|c|c|c|c|c|c|}
\hline \multirow{2}{*}{\multicolumn{2}{|c|}{ Model }} & \multicolumn{2}{|c|}{ Unstandardized Coefficients } & \multirow{2}{*}{$\begin{array}{c}\text { Standardized } \\
\text { Coefficients } \\
\text { Beta }\end{array}$} & \multirow[t]{2}{*}{$\mathrm{t}$} & \multirow[t]{2}{*}{ Sig. } \\
\hline & & B & Std. Error & & & \\
\hline \multirow{4}{*}{1} & (Constant) & 1.573 & 1.056 & & 1.489 & .142 \\
\hline & $\mathrm{X} 1$ & .106 & .363 & .038 & .291 & .772 \\
\hline & $\mathrm{X} 2$ & .064 & .092 & .094 & 690 & .493 \\
\hline & $\mathrm{X} 3$ & .354 & .375 & .128 & .944 & .349 \\
\hline \multicolumn{7}{|c|}{ a. Dependent Variable: ABS_RES } \\
\hline
\end{tabular}

Uji $\mathrm{F}$ bertujuan untuk menguji apakah semua variabel independen secara simultan berpengaruh terhadap variabel dependen (Utama, 2009: 71). Perumusan hipotesis pada uji f yaitu; $\mathrm{H}_{0}: \mathrm{b}_{1}=\mathrm{b}_{2}=\mathrm{b}_{3}=0$ yang berarti seluruh variabel berpengaruh positif dan signifikan secara simultan terhadap perilaku pembelian impulsif buying online. $\mathrm{H}_{1}: \mathrm{b}_{1} \neq \mathrm{b}_{2} \neq \mathrm{b}_{3} \neq 0$ yang berarti seluruh variabel tidak berpengaruh positif dan signifikan secara simultan terhadap perilaku pembelian impulsif buying online. Penerimaan dan penolakan daerah kritits atas hipotesis yang diajukan yaitu apabila nilai signifikansi lebih kecil dari 0,05 maka Ho 
diterima begitu pula sebaliknya jika nilai signifikansi lebih besar dari 0,05 maka Ho ditolak. Hasil perhitungan uji f dapat dilihat pada Tabel 16 sebagai berikut:

Tabel 16.

Hasil Uji F

ANOVA $^{\mathrm{a}}$

\begin{tabular}{rlrrrrr}
\hline Model & & Sum of Squares & df & Mean Square & F & Sig. \\
& & & & & & \\
\hline \multirow{3}{*}{1} & Regression & 232.319 & 3 & 77.440 & 9.616 & $.000^{\mathrm{b}}$ \\
& Residual & 499.331 & 56 & 8.917 & & \\
& Total & 731.650 & 59 & & & \\
\hline
\end{tabular}

a. Dependent Variable: Y

b. Predictors: (Constant), X3, X1, X2

Sumber: Data Primer Diolah, 2018

Tabel 16 menunjukan nilai dari signifikansi pada tabel sebesar 0,00. Berdasarkan nilai tersebut dapat disimpulkan bahwa model dapat dikatakan fit yang berarti Ho diterima yang menyatakan seluruh variabel bebas secara simultan berpengaruh terhadap variabel terikat, sesuai dengan kriteria yang telah ditentukan yaitu nilai signifikansi lebih kecil dari 0,05 maka Ho diterima dan $\mathrm{H}_{1}$ ditolak.

Uji $\mathrm{t}$ digunakan untuk mengetahui seberapa besar pengaruh variabel independen terhadap variabel dependen secara parsial. Rumusan hipotesis pada uji t yaitu; $H_{0}: b_{1}=b_{2}=b_{3}=0$ yang berarti seluruh variabel berpengaruh positif dan signifikan secara parsial terhadap perilaku pembelian impulsif buying online. $H_{1}: b_{1} \neq b_{2} \neq b_{3} \neq 0$ yang berarti seluruh variabel tidak berpengaruh positif dan signifikan secara parsial terhadap perilaku pembelian impulsif buying online. Kriteria penentuan daerah kritis pada uji t yaitu apabila $\mathrm{t}$ hitung $>\mathrm{t}$ tabel $(5 \%)$ maka $\mathrm{H}_{1}$ diterima. Hasil dalam uji t dapat dilihat pada Tabel 17. 
Tabel 17.

Hasil Uji t

\begin{tabular}{|c|c|c|c|c|c|c|}
\hline \multirow[t]{2}{*}{ Mod } & & \multicolumn{2}{|c|}{ Unstandardized Coefficients } & \multirow{2}{*}{$\begin{array}{c}\text { Standardized } \\
\text { Coefficients } \\
\text { Beta }\end{array}$} & \multirow[t]{2}{*}{$\mathrm{t}$} & \multirow[t]{2}{*}{ Sig. } \\
\hline & & B & Std. Error & & & \\
\hline \multirow{4}{*}{1} & (Constant) & .729 & 2.820 & & .258 & .797 \\
\hline & $\mathrm{X} 1$ & .311 & .044 & .320 & 2.282 & .025 \\
\hline & $\mathrm{X} 2$ & .583 & .079 & .479 & 4.299 & .004 \\
\hline & X3 & .273 & .120 & .272 & 2.266 & .036 \\
\hline
\end{tabular}

Sumber: Data Primer Diolah, 2018

Pada Tabel 17 nilai signifikansi variabel gender sebesar 0,025, variabel daya tarik promosi sebesar 0,004 dan variabel kepemilikan kartu kredit sebesar 0,036. Bedasarkan pemaparan Tabel 17 dapat diketahui nilai t signifikansi seluruh variabel $<0,05$ yang memiliki arti semua varibel bebas berpengaruh positif dan signfikan secara parsial terhadap variabel terikat, sehingga dapat disimpulkan bahwa Ho diterima.

\section{Pengaruh Gender Terhadap Perilaku Pembelian Impulsif Online Pada Produk Lifestyle}

Hasil uji parsial pada variabel gender menunjukan bahwa variabel gender berpengaruh signifikan terhadap perilaku impulsif online, dikarenakan nilai dari koefisien beta pada variabel gender bernilai positif, Nilai signifikansi variabel gender lebih kecil dari taraf signifikansi yang ditentukan yaitu 0,05. Nilai signifikansi variabel gender sebesar 0,02 hal ini membuktikan bahwa hipotesis pertama diterima yang berarti gender berpengaruh positif dan signifikan terhadap perilaku pembelian impulsif online di Kota Denpasar.

Hipotesis ini didukung oleh penelitian sebelumnya yang dilakukan oleh Tifferet dan Ram (2012) menyatakan bahwa perempuan memiliki dorongan yang 
lebih tinggi dalam pembelian dibandingkan dengan laki-laki. Penelitian ini juga didukung oleh Sarwono (2014) dalam Rani (2012) yang menyatakan remaja putri lebih mudah terpengaruh oleh bujukan teman, remaja putri juga lebih emosional dalam melakukan pembelian, sehingga remaja putri lebih cenderung impulsif dalam pembelian.

\section{Pengaruh Daya Tarik Promosi Terhadap Perilaku Pembelian Impulsif Online Pada Produk Lifestyle}

Daya tarik promosi dalam penelitian ini berpengaruh signifikan berdasarkan nilai dari data yang diperoleh. Hipotesis kedua pada penelitian ini membuktikan bahwa adanya pengaruh positif dan signifikan antara daya tarik promosi terhadap perilaku pembelian impulsif online di Kota Denpasar.

Hasil Penelitian ini didukung oleh Kurniawan et al. (2013) yang menyatakan bahwa daya tarik promosi berpengaruh positif dan signifikan terhadap pembelian impulsif online karena saat promosi gencar dilakukan oleh penyedia jasa online, maka konsumen akan lebih tertarik untuk melakukan impulsif online. Penelitian ini juga serupa dengan penelitian yang dilakukan oleh Mahaputra (2014), Chandra (2014) yang menyatakan adanya hubungan yang signifikan berpengaruh positif antara daya tarik promosi dan perilaku impulsif online di Indonesia.

\section{Pengaruh Kepemilikan Kartu Kredit Terhadap Perilaku Pembelian Impulsif Online Pada Produk Lifestyle}

Hasil penelitian ini menyatakan bahwa kepemilikan kartu kredit berpengaruh positif dan signifikan terhadap perilaku impulsif online konsumen di 
Kota Denpasar, terbukti dari nilai signifikansi variabel kepemilikan kartu kredit sebesar 0,03 yang lebih kecil dari nilai yang diharapkan $(0,05)$ serta nilai koefisien beta yang positif yang berarti konsumen yang memiliki kartu kredit lebih impulsif begitu pula sebaliknya jika nilai beta bersifat negatif.

Penelitian ini didukung oleh Saleh (2012) menyatakan bahwa kartu kredit berpengaruh positif terhadap perilaku pembelian impulsif karena semakin besar limit kartu kredit konsumen, maka lebih cenderung konsumen tersebut melakukan pebelian impulsif. Sulistyawaty (2012) menyatakan untuk sebagian kalangan, kartu kredit bahkan mendukung gaya hidupnya dan dimanfaatkan pada hampir semua transaksi pembelian barang atau jasa. Kartu kredit menjadi alat pembayaran barang yang sangat nyaman untuk digunakan dan menjadi sebuah alat transaksi yang patut dimiliki oleh semua orang baik dalam melakukan pembelanjaan secara online maupun langsung.

\section{Implikasi Hasil Penelitian}

Implikasi hubungan antara temuan dalam penelitian ini diharapkan mampu memberi manfaat serta strategi nyata bagi perusahaan yang sedang memasarkan produk atau jasa secara online. Bagi pihak pemasar yang menjual produk secara online, diharapkan mampu menekankan daya tarik promosi produk yang dipasarkan secara online, dikarenakan kemajuan globalisasi yang mendorong teknologi menjadikan konsumen dapat melihat hingga melakukan pembelian sebuah produk tanpa harus langsung melihat ke gerai toko, namun dengan online konsumen dapat melakukan pembelian terencana maupun tidak terencana. 
Para pemasar hendaknya mampu melihat market pasar yang dituju sebelum melakukan pemasaran secara online. Pemasar juga harus memperhatikan faktor demografi konsumen salah satunya jenis kelamin yang akan dijadikan sasaran dalam penjualan produknya. Dalam penelitian ini perempuan cenderung lebih sering melakukan pembelanjaan secara tidak terencana secara online. Terlepas dari itu, promosi yang dilakukan pemasar harus mampu tersampaikan kepada para konsumen. Dengan meningkatkan daya tarik promosi seperti pemberian diskon, sampel gratis serta voucer terbukti mampu memberikan dampak perilaku impulsif secara online.

Dalam melakukan penjualan secara online, pemasar juga harus memperhatikan proses transaksi pembayaran yang ditempuh. Pada penelitian ini alat pembayaran kartu kredit mampu mendorong perilaku impulsif online. Konsumen yang memiliki kartu kredit merasa terpacu dalam membeli barang saat sedang online, itu dikarenakan konsumen memiliki pegangan kartu kredit yang memberikan kenyamanan serta kemudahan dalam bertransaksi. Ini membuka peluang bagi para pemasar dalam memasarkan produknya secara online dan mampu menyediakan fasilitas pembayaran dengan menggunakan kartu kredit yang mendorong konsumen untuk berprilaku impulsif. Kemudahan dan kepercayaan dalam bertransaksi juga merupakan hal yang harus ditekankan bagi perusahaan yang akan memasarkan produk secara online. 
I Made Santika Putra, Pengaruh Gender, Daya Tarik...

\section{SIMPULAN DAN SARAN}

Berdasarkan hasil pembahasan maka dapat kesimpulan yang dapat diberikan yaitu; Gender berpengaruh positif dan signifikan terhadap perilaku pembelian impulsif secara online pada produk lifestyle. Dalam penelitian ini konsumen perempuan memiliki sifat impulsif yang lebih tinggi dari pada konsumen laki-laki. Daya tarik promosi berpengaruh positif dan signifikan terhadap perilaku pembelian impulsif secara online pada produk lifestyle. Semakin menarik daya tarik promosi yang dilakukan secara online oleh pemasar, maka akan meningkatkan perilaku pembelian impulsif secara online. Kepemilikan kartu kredit berpengaruh positif dan signifikan terhadap perilaku pembelian impulsif online. Dalam penelitian ini konsumen yang memiliki kartu kredit lebih impulsif dalam melakukan pembelian dari pada konsumen yang tidak memiliki kartu kredit. Dengan adanya kartu kredit mampu memicu konsumen untuk melakukan pembelian tidak terencana karena kelebihan yang diberikan oleh kartu kredit. Hal ini memberikan suatu hal positif bagi para pemasar agar bisa memberikan layanan pembayaran menggunakan kartu kredit saat bertransaksi secara online.

Saran yang dapat di tarik berdasarkan hasil pembahasan yaitu; Bagi para pemasar yang memanfaatkan internet untuk memasarkan produknya, diharapkan dapat meningkatkan pemberian sampel gratis karena pada penelitian ini, pemberian sampel gratis dapat meningkatkan minat membeli produk secara impulsif. Para pemasar juga harus mampu memanfaatkan media-media maupun situs-situs penjualan untuk meningkatkan penjualan. Para pemasar juga harus mempertimbangkan untuk bekerja sama dengan pihak bank untuk mendapatkan 
diskon ataupun potongan terkait dengan pembayaran menggunakan kartu kredit untuk mempermudah transaksi serta pemasar harus mengetahui sifat konsumen saat sedang berbelanja online, yang pada penelitian ini konsumen sering berpikir belakangan dan sering tidak sadar akan apa yang telah di beli secara online, ini memberikan peluang bagi para pemasar dalam memasarkan produk secara online. Bagi para peneliti selanjutnya diharapkan mampu mengembangkan penelitian dengan mempertimbangkan variabel yang lain terkait dengan perilaku konsumen dalam melakukan pembelian tidak terencana secara online, seperti persepsi keamanan dan lainnya. Selain itu, mengulas lebih dalam lagi produk lifestyle terhadap perilaku pembelian impulsif online, serta dampak kartu kredit terhadap perilaku pembelian impulsif online yang dapat dijadikan refrensi bagi perusahaan ataupun pemasar online.

\section{DAFTAR RUJUKAN}

Ali Asim, and S.A.F Hasnu. 2013. An Analysis Of Consumers' Characteristics On Impulse buying: Evidence From Pakistan. Interdisciplinary Journal of Contemporary Research in Business, 15(2), pp: 560-570.

Arifianti, Ria (2011).Pengaruh Promosi Penjualan Terhadap Impulse buying Pada Hypermart Di Kota Bandung.eprints.undip.ac.id., 12 (2)hal.45-70

Arnott, David, C., and Susan Bridgewater. 2002. Internet, Interaction and Implications for Marketing. Marketing Intelligence dan Planning, 20 (2):86-95.

BankBI.DataSistemPembayaranwww.bi.go.id/id/statistik/metadata/sistempembay aran/Documents/MetadataAPMK. Diakses tanggal 23 Oktober 2017.

Chandra, I Komang Agus. 2014. Pengaruh Jenis Kelamin, Promosi Penjualan Dan Sifat Materialisme Terhadap Perilaku Impulse Buying Secara Online. Skripsi Sarjana Jurusan Manajemen Faskultas Ekonomi dan Bisnis Universitas Udayana, Bali

Cummins, Julian dan Mullin, Roddy. 2004. Sales Promotion. Jakarta: PPM. 
I Made Santika Putra, Pengaruh Gender, Daya Tarik...

Ferdinand. 2002. Metode Penelitian Manajemen. Semarang: Universitas Diponegoro.

Fitriani, R. 2010. Studi Tentang Impulse buying Pada Hypermarket Di Kota Semarang. Skripsi Sarjana Jurusan Manajemen Faskultas Ekonomi dan Bisnis Universitas Diponegoro, Semarang

Goh, Y. S., N. Priambodo, and M. D. Shieh. 2012. Online Shopping Behavior in Taiwan and Indonesia. The Asian Conference on Media and Mass Communication, pp: 97-107

Graa, Amel, Dani-Elkebir, Maachou, Bensaid, Mohamed. 2014. The Impact of Environmental Factors on Impulse buying Behavior Using the Mehrabian and Russell's Framework. Leonardo Journal of Sciences, pp: 101-114.

Halomeney.co.id. Pengertian Kartu Kredit, Pilihan Jenis dan Cara Menghitung Bunga.https://www.halomoney.co.id/blog/pengertian-kartukredit.Diakses tanggal 23 Oktober 2017.

Karbasivar A., and H. Yarahmadi. 2011. Evaluating Effective Factors on Consumers Impulse buying behaviour. Asian Journal of Business Management Studies, 2(4): 174-181.

Kotler, Philip dan Kevin K. Keller. 2009, Manajemen Pemasaran. Edisi 13 Jilid 1, Jakarta: Penerbit Salemba Empat.

Kotler, Philip dan Kevin Lane Keller. (2009). Manajemen Pemasaran Edisi ke TigabelasJilid 2. Erlangga, Jakarta.

Kurniawan D., dan Y. S. Kunto. 2013. Pengaruh Promosi dan Store Atmosfer Terhadap Impulse buying dengan Shoping Emotion Sebagai Variabel Intervening Studi Kasus di Matahari Departement Store Cabang Supermall Surabaya, Jurnal Manajemen Pemasaran Petra, 1(2), hal.1-8.

Liputan6.com. Inilah 3 Kategori Produk yang Paling Digemari Saat Belanja Online. $\quad$ http://lifestyle.liputan6.com/read/2673582/inilah-3-kategoriproduk-yang-paling-digemari-saat-belanja-online. Diakses tanggal 11 Desember 2017.

Mahaputra, A.A. Ngr Bagus. 2014. Pengaruh Kecanduan Internet, Daya tarik Promosi dan Kepemilikan Kartu Kredit Terhadap Perilaku Pembelian Impulsif Online. Jurnal Manajemen Universitas Udayana, 4 (1), hal.209-

Mudzalifa, Yulias.2015. Faktor Faktor yang Mempengaruhi Keputusan Pembelian Impulsif Pada Lipstik Sari Ayu Di Basko Grand Mall Padang. Padang : jurnal ekonomi (STKIP) PGRI Sumatera Barat.

Park, H., and Burns, L. (2005). Fashion Orientation, Credit Card use, and Compulsive Buying. Journal of Consumer Marketing, 22(3), pp: 135-141 
Park, M. and S. J. Lennon. 2009. Brand Name and Promotion In Online Shopping Contexts. Journal of Fashion Marketing and Management, 13(2), pp: $149-160$

Peter, J.P., and Olson, J.C. (1999). Consumer Behavior and Marketing Strategy. Boston: Irwin/McGraw-Hill.

Rani, Atika dan Sahrah Ahlimatus . 2012. Hubungan Antar Konformitas Dengan Perilaku Membeli Impulsif Pada Remaja Putri. eJournal Psikologiwangsa manggala. 1 (4), hal.33-39

Rook, D. W. and Fisher R. J. 1995, A Normative Influences on Impulsive Buying Behavior, Journal of Consumer Research, (22) December, pp: 305-313

Safakli, O.V. 2007. Motivating factors of credit card usage and ownership: evidence from Northern Cyprus, Investment Management and Financial Innovations. 4(4). pp: 123-136

Saleh, Mahmoud Abdel Hamid. 2012. An Investigation of the Relationship between Unplanned Buying and Post-purchase Regret. International Journal of Marketing Studies, 4( 4),Pp: 106-120

Saragih, Hoga dan Rizky Ramdhany. 2012. Pengaruh Intensi Pelanggan Dalam Berbelanja Online Kembali Melalui Media Teknologi Informasi Forum Jual Beli (FJB) KASKUS. Journal of Information Systems, 8(2), hal.100112

Sari, D.P.2013.Pengaruh lifestyle, Efek Komunitas, dan Fitur Produk Terhadap Keputusan Brand Switching Smartphone Blackberry Keproduk Lain. Jurnal Manajemen Bisnis.1 (2), hal.23-47

Sayono, Jusup Agus, Ujang Sumarwan, Noer Azam Achsani dan Hartoyo. 2009. Analisis Faktor-Faktor yang Mempengaruhi Kepemilikan, Penggunaan, Pembayaran, dan Peluang Terjadinya Gagal Bayar Dalam Bisnis Kartu Kredit. Jurnal Ekonomi \& Bisnis. 3(1): 61-80.

Sekaran, Uma. 2003 Researh methods For Business. New Jersey: John Willey \& Sons inc.

Sugiyono. 2010, Metode Penelitian Bisnis. Bandung: Alfabeta.

Suharso, Puguh. 2010. Model Analisis Kuantitatif “TEV”. Jakarta: Indeks

Sulistyawaty R. 2012. Perilaku konsumen dalam penggunaan kartu kredit di wilayah DKI Jakarta. Jurnal Ekonomi Bisnis, 22 (3),Hal.255

Tempo.com.Kartu Kredit Sudah Beredar 1681 juta keping.https://bisnis.tempo.co/ read/746330/lebih-optimis-kartu-kredit-sudah-beredar- 1681-juta-keping. Diakses tanggal 23 Oktober 2017 
I Made Santika Putra, Pengaruh Gender, Daya Tarik...

Tifferet, S., and Ram, H. Gender differences in brand commitment, impulse buying, and hedonic consumption. The journal of Product and Brand Management 21 (3), pp:176-182

Tjiptono. 2008. Pemasaran Strategik. Andy. Yogyakarta

Utama, Made Suyana. 2012. Aplikasi Analisis Kuantitatif. Edisi Keenam. Buku ajar pada Fakultas Ekonomi Universitas Udayana.

Widawati, Lisa. 2011. Analisis perilaku "Impulse buying" dan "Locus of Control" pada konsumen di Carrefour Bandung. MIMBAR, 27 (2), pp: 125-132. ISSN 0215-8175

Winatha, Regina G. 2013. Pengaruh Sifat Materialisme dan Kecanduan Internet Terhadap Perilaku Pembelian Tanpa Rencana Secara Online. Skripsi Sarjan Jurusan Manajemen Faskultas Ekonomi dan Bisnis Universitas Udayana, Bali 